\title{
Impact of Foliar Spraying with Antioxidant and Intercropping Pattern of Maize and Soybean on Yields and its Attributes \\ Said, M. T. ${ }^{1}$ and W. A. Hamd-Alla ${ }^{2}$ \\ ${ }^{1}$ Agronomy Department, Faculty of Agriculture, Assiut University, Assiut, Egypt \\ ${ }^{2}$ Department of Crop Intensification Research, Field Crops Research Institute, Agricultural Research Center, Giza, Egypt.
}

\section{ABSTRACT}

In order to study the effect of foliar spray by antioxidant (salicylic and ascorbic acids) and intercropping patterns on the production of both maize and soybean. Two field experiments were conducted at Agronomy Department Farm, Agriculture Faculty, Assiut University, Assiut, Egypt during 2016 and 2017 seasons. Two factors were studied, the first one was foliar application of Antioxidant compounds (control, ascorbic acid at $200 \mathrm{ppm}$, salicylic acid at $200 \mathrm{ppm}$ and ascorbic acid + salicylic acid at $200 \mathrm{ppm}$ ). Four intercropping patterns were used (maize-soybean 2:2, maize-soybean 2:1, sole maize and sole soybean) as a second factor. The obtained results showed that: The results indicated that foliar spraying with antioxidant and intercropping patterns enhanced significantly all traits in this study except plant height of maize in both seasons. Thus, the highest values of measured traits where observed from plants which sprayed with salicylic acid at rate of $200 \mathrm{ppm}$ of the two crops in the two successful seasons. Maximum yield and its attributes of maize were produced from the sole maize sown followed by the intercropping pattern of 2:1 of maize and soybean in both seasons. In addition, maximum soybean yield and its related traits were produced from the sole sown followed by the intercropping pattern 2:2 of maize and soybean in both seasons. It could be concluded that intercropping pattern 2:2 of maize and soybean with foliar spraying salicylic acid at rate of $200 \mathrm{ppm}$ recorded the maximum of land equivalent ratio (LER) and monetary advantage index (MAI) of the unit area under Assiut Government condition.

Keywords: Maize, Soybean, Intercropping Patterns, Ascorbic and Salicylic Acid.

\section{INTRODUCTION}

Intercropping is an important agronomic strategy that involves the growing of two or more crops on the same site of soil (Katyayan, 2005), maximizes production as well as resource utilization per unit area, provide 15$20 \%$ of food supply to the world (Lithourgidis et al., 2011). Also it has ecological and biological advantages over sole cropping (He et al., 2012 and Waktola et al., 2014). Cereal-legume (maize-soybean) intercropping is a maintainable land management practice (Regehr et al., 2015). Additionally, it helps to sustain and expand the soil fertility because leguminous crops like soybean accumulate nitrogen from 80 to $350 \mathrm{~kg} / \mathrm{ha}$ (Mobasser et al., 2014). ElEdward et al. (1985) found that weight of 100-grain, grain yield and LER, increased when soybean was intercropped with maize. Metwally et al. (2005) and Aziz et al. (2012) concluded that intercropping with 2-row maize: 2-row soybean give higher yield, LER and net return than other intercropping patterns. The maize yield and its components was decreased under maize-soybean intercropped as compared with sole maize (Abou-Keriasha et al. 2012 and Abrar et al. 2016). However, Abrar et al. 2016 illustrated that the maximum seed yield and its components of soybean were higher in sole compared with different intensities of intercropping, thus, the maximum seed yield of soybean $(1.20 \mathrm{t} / \mathrm{ha})$ was recorded in sole soybean crop followed by 2 row maize: 2 rows soybean $(0.46 \mathrm{t} / \mathrm{ha})$. While, the minimum seed yield ( $0.34 \mathrm{t} / \mathrm{ha})$ was recorded in case of double row maize: one row of soybean. Hamd Alla et al. (2014) found tallest maize plants under intercropping system as compared with sole maize.

Salicylic acid (SA), a naturally plant hormone, turns as an endogenous signal molecule responsible for inducing a biotic stress tolerance in plants (Gunes et al., 2007). Exogenous application of salicylic acid may be contributed in physiological processes, such as stomatal conductance, menerals uptake, membrane activity and photosynthesis hence affected growth Borsani et al. (2001), and he add that spraying of salicylic acid affected the nutrient balances in the plant as reported by. Ascorbic acid (AS) is considered as the most famous growth regulators under abiotic stress conditions (Conklin, 2001). Not only AS acts as an antioxidant, but also the cellular levels of AS are correlated with the activation of complex biological defense mechanisms (Conklin and Barth, 2004). Furthermore, experimental studies on dissimilar crops have shown that foliar application of AS may reduce drought stress effects leading to an increment of growth and yield (Salama, 2009).

Therefore, the objective of this research was aimed to estimate the effect of antioxidant foliar application and intercropping patterns on maize and soybean yields and other yields related characters.

\section{MATERIALS AND METHODS}

\section{Experimental site}

Current study was conducted at Agronomy Department Farm, Faculty of Agriculture, Assiut University, Egypt lat. $\left(27^{\circ} 18^{\prime} \mathrm{N}\right.$, long. $31^{\circ} 16^{\prime}$ and alt. $53 \mathrm{~m}$ a.s.1.) during 2016 and 2017. The preceding crop was wheat in both seasons. The soil properties of experimental site are shown in Table 1.

Table 1. Some physical and chemical properties of representative soil samples of the experimental site before sowing $(0-30 \mathrm{~cm}$ depth) for the two growth seasons.

\begin{tabular}{lcc}
\hline Soil property & 2016 season* & 2017 season* \\
\hline Particle - size distribution & & \\
Silt (\%) & 26.4 & 26.3 \\
Sand (\%) & 24.3 & 25.2 \\
Clay (\%) & 49.3 & 48.5 \\
Texture & Clay & Clay \\
Organic matter (\%) & 1.70 & 1.75 \\
Field capacity (\%) & 42.8 & 43.2 \\
EC $\left(1: 1\right.$ extract) $\left(\mathrm{dS} \mathrm{m}{ }^{-1}\right)$ & 0.77 & 0.73 \\
pH $(1: 1$ suspension) & 8.2 & 8.3 \\
Total nitrogen $(\%)$ & 0.72 & 0.69 \\
CaCO $(\%)$ & 3.5 & 3.6 \\
$\mathrm{KCl}_{3}$-extractable N (mg kg & \\
$\mathrm{NaHCO}_{3}$-extractable $\mathrm{P}\left(\mathrm{mg} \mathrm{kg}^{-1}\right)$ & 42.23 & 41.26 \\
$\mathrm{NH}_{4} \mathrm{OAC}^{-1}$-extractable K $\left(\mathrm{mg} \mathrm{kg}^{-1}\right)$ & 4.32 & 4.72 \\
\hline
\end{tabular}

* Each value represents the mean of three replications.

Experimental design and treatments: -

Field experiments were laid out in randomized complete block design (RCBD) using strip plot arrangement with three replications. The first variable was four foliar application treatments of Antioxidant compounds (control, 
ascorbic acid, salicylic acid and ascorbic acid + salicylic acid), which occupied in horizontal plots. Three equal foliar applications 10 days interval with antioxidant started at 20 days after sowing of maize by the following treatments:

1- Control (sprayed with water).

2- Ascorbic acid (200 ppm).

3- Salicylic acid (200 ppm).

4- Ascorbic acid + Salicylic acid (200 ppm).

While the second variable was intercropping patterns, which allocated in vertical plots. The intercropping patterns were as follows:

1- 2 maize : 2 soybean: Two maize ridges alternating with another two ridges of soybean. Maize was grown in one row/ridge (70 $\mathrm{cm}$ width) with leaving two plants/hill spaced at $40 \mathrm{~cm}$. Soybean seeds were drilled in two row/ridge, in two plants/hill spaced at $15 \mathrm{~cm}$.

2- 2 maize : 1 soybean: Two maize ridges alternating with another one of soybean. Maize was grown in one row/ridge $(70 \mathrm{~cm}$ width) with leaving two plants/hill spaced at $40 \mathrm{~cm}$. Soybean seeds were drilled in two row/ridge, in two plants/hill spaced at $15 \mathrm{~cm}$.

3- Sole maize: Maize was grown in one row $/$ ridge $(70 \mathrm{~cm}$ width) and thinned to one plant/hill, $30 \mathrm{~cm}$ apart between hills.

4- Sole soybean: Soybean seeds were drilled in two row/ridge, in two plants/hill spaced at $15 \mathrm{~cm}$.

The experimental unite area was $10.5 \mathrm{~m}^{2}$. Seeds of the early - maturing soybean variety Giza 111 were inoculated with Bradyrhizobium japonicum and Arabic gum was used as a sticking agent. Soybean seeds were sown on $11^{\text {th }}$ and $14^{\text {th }}$ May in 2016 and 2017 seasons, respectively. Meanwhile, maize hybrid Giza 128 (white single cross) was sown 15 days later. Soybean plants were harvested on $14^{\text {th }}$ and $16^{\text {th }}$ September in 2016 and 2017 seasons, respectively. Maize plants were harvested on $19^{\text {th }}$ and $21^{\text {th }}$ September in 2016 and 2017, respectively. Cultural management, disease and pest control programs for maize and soybean crops were followed as recommended by the Egyptian Ministry of Agriculture.

\section{Crop yield determination}

Maize traits:

At maturity, ten guarded plants of maize from each experimental unit were taken randomly and the plant height $(\mathrm{cm})$, number of rows/ear and weight of 100 kernels (g) were measured and the all harvested plants from each experimental unit were used to determine the grain yield $(\mathrm{kg} / \mathrm{fed})$ after adjustment the grains moisture to $15.5 \%$.

Soybean traits:

At maturity, ten guarded plants of soybean from each experimental unit were taken randomly and the plant height (cm), number of seed/plant and weight of 100 seed $(\mathrm{g})$ were measured and the all harvested plants from each experimental unit were used to determine the seed yield (ton/fed).

\section{Competitive relationships}

\section{Land equivalent ratio (LER)}

Defined as the ratio of area needed under sole cropping to intercropping system at the same management level to gain an equivalent yield (Willey, 1979). It is calculated as follows:

$$
\mathbf{L E R}=\left(\mathbf{Y}_{\mathbf{a b}} / \mathbf{Y}_{\mathbf{a a}}\right)+\left(\mathbf{Y}_{\mathbf{b a}} / \mathbf{Y}_{\mathbf{b b}}\right)
$$

Where $Y_{a a}=$ Pure stand yield of $\operatorname{crop}(a) ; Y_{b b}=$ Pure stand yield of crop (b); $Y_{a b}=$ Intercrop yield of crop a and $Y_{b a}=$ Intercrop yield of crop $b$.

\section{Monetary advantage index (MAI)}

Suggests that the economic assessment should be in terms of the value of land saved, this could probably be most assessed on the basis of the rentable of this land. MAI was calculated according to the formula, suggested by (Willey, 1979):

$$
\begin{gathered}
\text { MAI }=\frac{\text { Value of combined intercrops } \times \text { LER }-\mathbf{1}}{\text { LER }} \\
\text { In Egyptian pound maize price was } 2.45 \text { L.E. } / \mathrm{kg} \text { for }
\end{gathered}
$$
grain yield and soybean was 4388 L.E./ton for seed yield of the two seasons (Bulletin of Statistical Cost Production and Net Return, 2017).

\section{Statistical analysis:}

Collected data were analyzed by MSTAT-C (1991) software package according to Gomez and Gomez (1984). Means were compared using revised Least Significant Difference (RLSD) at 5\% level of significant (Steel and Torrie, 1981).

\section{RESULTS AND DISCUSSION}

Effect of antioxidants on yields and its attributes of maize and soybean.

Concerning, maize traits results presented in Table 2 showed that foliar spray of maize plants by salicylic and /or ascorbic acid enhanced significantly all studied traits except plant height in both seasons as compared to the control treatment. Thus, the highest number of rows/ear (13.2 and 13.8), weight of 100 kernels (39.8 and $40.8 \mathrm{~g}$ ) and grain yield ( 2489.5 and $2643.9 \mathrm{~kg} / \mathrm{fed})$ in the first and second seasons, respectively were obtained from sown maize plants which were sprayed by 200 ppm of salicylic acid (SA). These findings are in harmony with those obtained by Borsani et al. (2001), Khan et al. (2003), Gunes et al. (2007), Tufail et al. (2013) Said and Abd El-

\begin{tabular}{|c|c|c|c|c|}
\hline Antioxidant & Plant height (cm) & Number of rows/ear & Weight of 100 kernels (g) & Grain yield (kg/fed) \\
\hline & & Season 2016 & & \\
\hline Control & 203.2 & 12.6 & 38.3 & 2213.4 \\
\hline Ascorbic acid at $200 \mathrm{ppm}$ & 200.8 & 12.9 & 39.0 & 2394.8 \\
\hline Salicylic acid at $200 \mathrm{ppm}$ & 204.8 & 13.2 & 39.8 & 2489.5 \\
\hline Ascorbic + Salicylic acids at $200 \mathrm{ppm}$ & 206.0 & 12.8 & 38.6 & 2298.7 \\
\hline F test & NS & $* *$ & $* *$ & $* *$ \\
\hline Rev L.S.D 0.05 & - & 0.2 & 0.3 & 49.8 \\
\hline & & Season 2017 & & \\
\hline Control & 203.0 & 13.1 & 39.4 & 2371.0 \\
\hline Ascorbic acid at $200 \mathrm{ppm}$ & 204.1 & 13.6 & 40.1 & 2551.2 \\
\hline Salicylic acid at $200 \mathrm{ppm}$ & 205.9 & 13.8 & 40.8 & 2643.9 \\
\hline Ascorbic + Salicylic acids at $200 \mathrm{ppm}$ & 204.6 & 13.4 & 39.7 & 2456.4 \\
\hline F test & NS & $* *$ & $* *$ & $* *$ \\
\hline Rev L.S.D 0.05 & - & 0.2 & 0.5 & 109.8 \\
\hline
\end{tabular}
Moneem (2016) and Ahmad et al. (2018).

Table 2. Effect of antioxidant foliar spraying on yield and its attributes traits of maize during 2016 and 2017 seasons

NS and ** means not significant, significant at 0.05 and 0.01 probability, respectively. 
Regarding soybean traits, results presented in Table 3 revealed that the investigated foliar spraying with salicylic and /or ascorbic acid at rate of $200 \mathrm{ppm}$ had significant effects on all studied traits in both seasons. Thus, tallest plants $(108.5$ and $116.7 \mathrm{~cm})$, higher number of seed/plant (87.3 and 94.0), heaviest 100 seed (17.9 and $20.1 \mathrm{~g})$ and higher seed yield $(0.726$ and $0.755 \mathrm{ton} / \mathrm{fed})$ in both seasons, respectively, were obtained from soybean plants which were spraying by 200 ppm of salicylic acid
(SA). These findings are in harmony with those obtained by Jaiswal et al. (2014).

The previous results could be attributed to the fact that SA enhances growth vigor of plants and increased plant growth due to exogenous application of salicylic acid may be contributed in physiological processes, such as stomatal conductance, minerals uptake, membrane activity and photosynthesis hence affected growth as reported by Borsani et al. (2001).

Table 3. Effect of antioxidant foliar spraying on yield and its attributes traits of soybean during 2016 and 2017 seasons

\begin{tabular}{lcccc}
\hline Antioxidant & Plant height (cm) & Number of seed/plant & Weight of 100 seed (g) & Seed yield (ton/fed) \\
\hline & & Season 2016 & 16.6 & 0.661 \\
Control & 96.5 & 83.7 & 17.7 & 0.706 \\
Ascorbic acid at 200 ppm & 104.7 & 86.2 & 17.9 & 0.726 \\
Salicylic acid at 200 ppm & 108.5 & 87.3 & 17.1 & 0.692 \\
Ascorbic + Salicylic acids at 200 ppm & 97.5 & 85.1 & $*$ & $* .9$ \\
F test & $* *$ & 0.8 & 18.7 & 0.014 \\
Rev L.S.D 0.05 & 3.0 & Season 2017 & 19.9 & 0.706 \\
Control & 103.5 & 89.9 & 20.1 & 0.755 \\
Ascorbic acid at 200 ppm & 112.6 & 92.7 & 19.3 & 0.720 \\
Salicylic acid at 200 ppm & 116.7 & 94.0 & $*$ & $*$ \\
Ascorbic + Salicylic acids at 200 ppm & 105.0 & 91.6 & 0.9 & 0.031 \\
F test & $* *$ & $* *$ & & \\
Rev L.S.D 0.05 & 3.6 & 1.0 & &
\end{tabular}

* and ** means significant at 0.05 and 0.01 probability, respectively.

Effect of intercropping patterns on yields and its attributes of maize and soybean.

Results presented in Table 4 showed that intercropping patterns had a significant effect on all studied traits in both seasons except plant height in the first season. The tallest maize plants produced from intercropping pattern of 2:2 followed by pattern of 2:1 in both seasons. Intercropping patterns $2: 2$ and $2: 1$ had the tallest plants compared with sole in both season, those may be due to competition of associated crops for intercepted the light intensity compared with sole maize. Similar results were observed by Hamd Alla et al. (2014). Maximum number of row/ear, 100 grain weight and grain yields of maize were produced from the sole maize followed by the pattern $2: 1$. While, the lowest values of previous traits were obtained from the pattern $2: 2$. The highest maize grain yield in sole and 2:1 pattern may be due to higher population. These results are agreement with those obtained by Abou-Keriasha et al. (2012) and Abrar et al. (2016).

Table 4. Effect of intercropping patterns on yield and its attributes traits of maize during 2016 and 2017 seasons.

\begin{tabular}{|c|c|c|c|c|}
\hline $\begin{array}{l}\text { Intercropping } \\
\text { patterns }\end{array}$ & $\begin{array}{c}\text { Plant } \\
\text { height } \\
\text { (cm) }\end{array}$ & $\begin{array}{c}\begin{array}{c}\text { Number } \\
\text { of } \\
\text { rows/ear }\end{array} \\
\end{array}$ & $\begin{array}{l}\text { Weight of } \\
100 \\
\text { kernels (g) }\end{array}$ & $\begin{array}{c}\text { Grain } \\
\text { yield } \\
(\mathrm{kg} / \text { fed })\end{array}$ \\
\hline \multicolumn{5}{|c|}{ Season 2016} \\
\hline $2: 1$ & 203.6 & 12.8 & 38.5 & 2332.1 \\
\hline $2: 2$ & 204.9 & 12.3 & 37.8 & 2009.1 \\
\hline Sole & 202.6 & 13.4 & 40.5 & 2706.1 \\
\hline F test & NS & $* *$ & $* *$ & $* *$ \\
\hline Rev L.S.D 0.05 & - & 0.4 & 0.5 & 132.0 \\
\hline \multicolumn{5}{|c|}{ Season 2017} \\
\hline $2: 1$ & 203.7 & 13.4 & 39.7 & 2499.7 \\
\hline $2: 2$ & 207.6 & 12.9 & 38.7 & 2140.8 \\
\hline Sole & 201.8 & 14.1 & 41.6 & 2876.3 \\
\hline F test & $* *$ & $* *$ & $* *$ & $* *$ \\
\hline Rev L.S.D ${ }_{0.05}$ & 0.4 & 0.5 & 0.6 & 122.7 \\
\hline
\end{tabular}

NS and ** means not significant, significant at 0.05 and 0.01 probability, respectively.

Results presented in Table 5 cleared that the different intensities of intercropping affected significantly yield and its attributes of soybean in both seasons. Intercropping patterns 2:2 and 2:1 give the tallest plants compared with sole in both seasons. Those results may be due to competition of associated crops for intercepted the light intensity compared with sole maize. Maximum seed numbers/plant, weight of 100 seed and seed yield per feddan of soybean were recorded in sole soybean crop followed by pattern 2:2. Otherwise, the minimum seed numbers/plant, weight of 100 seed and seed yield per feddan were recorded in case of intercropping at 2:1 pattern. The reduction occurs in yield and its attributes may be due to the shading from top of maize plants to top of intercropped soybean which in turn decreased interception of solar radiation. Similar findings were obtained by Metwally et al. (2009), Abou-Keriasha et al. (2012) and Abrar et al. (2016).

Table 5. Effect of intercropping patterns on yield and its attributes traits of soybean during 2016 and 2017 seasons

\begin{tabular}{|c|c|c|c|c|}
\hline $\begin{array}{l}\text { Intercropping } \\
\text { patterns }\end{array}$ & $\begin{array}{c}\text { Plant } \\
\text { height } \\
\text { (cm) }\end{array}$ & $\begin{array}{c}\text { Number } \\
\text { of seed/ } \\
\text { plant }\end{array}$ & $\begin{array}{l}\text { Weight of } \\
100 \text { seed } \\
\text { (g) }\end{array}$ & $\begin{array}{c}\text { Seed } \\
\text { yield } \\
\text { (ton/fed) }\end{array}$ \\
\hline \multicolumn{5}{|c|}{ Season 2016} \\
\hline $2: 1$ & 101.4 & 79.9 & 16.4 & 0.350 \\
\hline $2: 2$ & 106.4 & 86.1 & 17.1 & 0.715 \\
\hline Sole & 97.6 & 90.7 & 18.5 & 1.023 \\
\hline F test & $* *$ & $* *$ & $* *$ & $* *$ \\
\hline Rev L.S.D ${ }_{0.05}$ & 2.2 & 0.9 & 0.7 & 0.033 \\
\hline \multicolumn{5}{|c|}{ Season 2017} \\
\hline $2: 1$ & 109.1 & 86.1 & 18.5 & 0.361 \\
\hline $2: 2$ & 114.1 & 92.5 & 19.2 & 0.736 \\
\hline Sole & 105.1 & 97.6 & 20.8 & 1.090 \\
\hline $\mathrm{F}$ test & $* *$ & $* *$ & $* *$ & $* *$ \\
\hline Rev L.S.D ${ }_{0.05}$ & 1.6 & 1.1 & 0.6 & 0.081 \\
\hline
\end{tabular}

** means significant at 0.05 and 0.01 probability, respectively.

Effect of the interaction between antioxidants and intercropping patterns on yields and its attributes of maize and soybean.

The results presented in Table 6 revealed that the interaction between antioxidants foliar spray and intercropping pattern couldn't exhibit any significant differences in all traits except weight of 100 kernels of maize in both seasons as well as seed yield (ton/fad) of soybean in the first season only. Thus, the highest of 100 kernel weight 
of maize (42.2 and $43.1 \mathrm{~g}$ ) in the first and second season, respectively. which produced from sole maize plants foliar spraying with $200 \mathrm{ppm}$ of salicylic acid. Meantime, the highest seed yield of soybean (1.048 ton/fed) in the first season was attended to sole soybean plants with foliar spraying with $200 \mathrm{ppm}$ of salicylic acid. These results are in harmony with those detected by Zilic et al. (2010) and Dragicevic et al. (2017).

Table 6. Effect of the interaction between antioxidant foliar spraying and intercropping patterns on maize and soybean during 2016 and 2017 seasons for significant traits only.

\begin{tabular}{|c|c|c|c|c|c|c|}
\hline \multirow{2}{*}{$\begin{array}{l}\text { Characters } \\
\text { Intercropping patterns Antioxidant }\end{array}$} & \multicolumn{3}{|c|}{ Weight of 100 kernels (g) of maize } & \multicolumn{3}{|c|}{ Seed yield (ton/fed) of soybean } \\
\hline & $2: 1$ & $2: 2$ & Sole maize & $2: 1$ & $2: 2$ & Sole soybean \\
\hline \multicolumn{7}{|c|}{ Season 2016} \\
\hline Control & 38.4 & 37.1 & 39.6 & 0.317 & 0.671 & 0.996 \\
\hline Ascorbic acid at $200 \mathrm{ppm}$ & 38.6 & 38.0 & 40.4 & 0.363 & 0.724 & 1.032 \\
\hline Salicylic acid at $200 \mathrm{ppm}$ & 38.9 & 38.5 & 42.2 & 0.369 & 0.759 & 1.048 \\
\hline Ascorbic + Salicylic acids at $200 \mathrm{ppm}$ & 38.4 & 37.6 & 39.8 & 0.351 & 0.708 & 1.018 \\
\hline F test & \multicolumn{3}{|c|}{$* *$} & \multicolumn{3}{|c|}{$* *$} \\
\hline$\underline{\text { Rev L.S.D }} 0.05$ & \multicolumn{3}{|c|}{0.5} & \multicolumn{3}{|c|}{0.13} \\
\hline & \multicolumn{3}{|c|}{ Season 2017} & & & \\
\hline Control & 39.4 & 38.1 & 40.7 & 0.351 & 0.708 & 1.060 \\
\hline Ascorbic acid at $200 \mathrm{ppm}$ & 39.8 & 39.1 & 41.6 & 0.366 & 0.739 & 1.099 \\
\hline Salicylic acid at $200 \mathrm{ppm}$ & 40.0 & 39.2 & 43.1 & 0.373 & 0.776 & 1.117 \\
\hline Ascorbic + Salicylic acids at $200 \mathrm{ppm}$ & 39.5 & 38.7 & 41.0 & 0.354 & 0.722 & 1.084 \\
\hline F test & \multicolumn{3}{|c|}{$*$} & \multicolumn{3}{|c|}{$\mathrm{NS}$} \\
\hline Rev L.S.D ${ }_{0.05}$ & \multicolumn{3}{|c|}{0.7} & \multicolumn{3}{|c|}{-} \\
\hline
\end{tabular}

NS, * and ** means not significant, significant at 0.05 and 0.01 probability, respectively.

Effect of antioxidants and intercropping patterns on Land equivalent ratio (LER) and Monetary advantage index (MAI) of maize and soybean.

Land equivalent ratio (LER)

Results presented in Table 7 revealed that land equivalent ratio (LER) values were greater than one in both seasons. Here too, it could be concluded that actual productivity was higher than the expected productivity. The results also showed that maize was superior of soybean in the antioxidant treatments and intercropping patterns. The SA and intercropping pattern of 2:2 give higher relative yields of maize $\left(\mathrm{RY}_{\mathrm{m}}\right)$ and relative yields of soybean $\left(\mathrm{RY}_{\mathrm{s}}\right)$ compared with the other treatments studied. The highest LER (1.48 and 1.46) in the two respective seasons were observed when salicylic acid was spraying on intercropping pattern 2:2 plants.
Similar results in this respect were observed by of Metwally et al. (2005), Aziz et al. (2012), AbouKeriasha et al. (2012) and Hamd Alla et al. (2014). Monetary advantage index (MAI)

Monetary advantage index (MAI) is considered an indicator of the economic feasibility of antioxidant and intercropping patterns, results recorded in Table 7 showed that the highest MAI values of 2663.98 and 2697.14 were obtained from foliar spraying salicylic acid at $200 \mathrm{ppm}$ with intercropping pattern of 2:2 in first and second seasons, respectively. These MAI values were positive due to LER which were greater than one. The previous results are in same line with those obtained by Abou-Keriasha et al. (2012) and Hamd Alla et al. (2014) who's stated that economic benefit expressed with the higher MAI values in intercropping.

Table 7. Effect of antioxidants and intercropping patterns on Land equivalent ratio (LER) and Monetary advantage index (MAI) of maize and soybean during 2016 and 2017.

\begin{tabular}{|c|c|c|c|c|c|c|c|c|}
\hline \multirow{3}{*}{$\begin{array}{l}\text { Characters } \\
\text { Intercropping patterns Antioxidant }\end{array}$} & \multicolumn{2}{|c|}{ Relative yield } & \multirow{3}{*}{ LER } & \multicolumn{2}{|c|}{ Relative yield } & \multirow{3}{*}{ LER } & \multirow{2}{*}{\multicolumn{2}{|c|}{ MAI }} \\
\hline & Maize & Soybean & & Maize & Soybean & & & \\
\hline & & 2:1 & & & $2: 2$ & & $2: 1$ & $2: 2$ \\
\hline \multicolumn{9}{|c|}{ Season 2016} \\
\hline Control & 0.89 & 0.32 & 1.21 & 0.76 & 0.67 & 1.43 & 1186.85 & 2284.11 \\
\hline Ascorbic acid at $200 \mathrm{ppm}$ & 0.85 & 0.35 & 1.20 & 0.73 & 0.70 & 1.43 & 1217.96 & 2477.00 \\
\hline Salicylic acid at $200 \mathrm{ppm}$ & 0.88 & 0.35 & 1.23 & 0.76 & 0.72 & 1.48 & 1341.09 & 2663.98 \\
\hline Ascorbic + Salicylic acids at $200 \mathrm{ppm}$ & 0.84 & 0.35 & 1.18 & 0.73 & 0.70 & 1.42 & 1174.31 & 2449.95 \\
\hline \multicolumn{9}{|c|}{ Season 2017} \\
\hline Control & 0.89 & 0.33 & 1.22 & 0.75 & 0.67 & 1.42 & 1363.18 & 2391.28 \\
\hline Ascorbic acid at $200 \mathrm{ppm}$ & 0.86 & 0.33 & 1.19 & 0.74 & 0.67 & 1.41 & 1237.09 & 2489.83 \\
\hline Salicylic acid at $200 \mathrm{ppm}$ & 0.88 & 0.33 & 1.22 & 0.76 & 0.69 & 1.46 & 1367.50 & 2697.14 \\
\hline Ascorbic + Salicylic acids at $200 \mathrm{ppm}$ & 0.85 & 0.33 & 1.18 & 0.73 & 0.67 & 1.39 & 1185.71 & 2439.04 \\
\hline
\end{tabular}

\section{CONCLUSION}

From the obtained results, it could be recommended that maximum land equivalent ratio and monetary advantage index were produced from intercropping pattern of 2:2 of maize and soybean plants which were sprayed with salicylic acid at rate of $200 \mathrm{ppm}$.

\section{REFERENCES}

Abou-Keriasha, M. A.; R. A. Gadallah and N. M. H. ElWakil Mohamed (2012). Effect of intra-interspecific competitions on yield and yield component of Maize under different intercropping patterns. Egypt. J. Agron. Res., 34(2): 249-265.
Abrar A; A. W. Muhammad; W. F. Muhammad; U. A. Muhammad; A. A. Muhammad and T. S. Muhammad (2016). Agro-Economic Assessment of Maize-Soybean Intercropping System. AmericanEurasian J. Agric. \& Environ. Sci., 16 (11): 17191725.

Agriculture Statistics (2017). Summer and Nili Field Crops and Vegetables and Fruit, Agriculture Statistics and Economic Sector, Ministry of Egyptian Agriculture and Land Reclamation, Part (2), August, Egypt.

Ahmad H.; I. Khan; W. Liaqat; M. F. Jan and M. D. Ahmadzai (2018). Effect of salicylic acid on yield and yield components of maize under reduced irrigation. Int J Environ Sci Nat Res., 9 (3): 1-5. 
Aziz, A.; M. Abou-Elela; A. A. Usama El-Razek and H. E. Khalil (2012). Yield and its components of maize/soybean intercropping systems as affected by planting time and distribution. Australian J. of Basic and Appl. Sci., 6: 238-245.

Borsani, O.; V. Valpuesta and M.A. Botella (2001). Effect of salicylic Acid on the evidence for a role of salicylic acid in the growth, photosynthesis and carbohydrate oxidative damage generated by $\mathrm{NaCl}$ and osmotic metabolism in salt-stressed maize plants. Plant Physiol., 126: 1024-1030.

Conklin, P. L. (2001). Recent advances in the role and biosynthesis of ascorbic acid in plants. Plant Cell Environ., 24: 383-394.

Conklin, P. L. and C. Barth (2004). Ascorbic acid, a familiar small molecule intertwined in the response of plants to ozone, pathogens and the onset of senescence. Plant Cell Environ., 27: 959-970.

Dragicevic V. D.; S. I. Oljaca; M. S. Simic; Z. K. Dolijanovic; B. J. Kresovic and M. Z. Brankov (2017). Content of some antioxidants in intercropped maize and soybean grain. J. of Agric. Sci., 62 (1): 31-40.

El-Edward, A.; A. Edris; A. Abu-Shetaia and A. Abd-ElGawad (1985). Intercropping soybean with maize. Competitive relationships and yield advantages. Annals of Agric. Sci., 30: 237-248.

Gomez, K. A. and A. A. Gomez (1984). Statistical Procedures for Agriculture Research $2^{\text {nd }}$ F. John Wiley and Sons. New York, 317-333.

Gunes, A.; A. Inal; M. Alpaslan; F. Eraslan; E.G. Bagci and N. Cicek (2007). Salicylic acid induced changes on some physiological parameters symptomatic for oxidative stress and mineral nutrition in maize ( $\mathrm{Zea}$ mays L.) grown under salinity, J. of Plant Physiol., 164 (6): 728-736.

Hamd Alla, W. A.; E. M. Shalaby; R. A. Dawood and A. A. Zohry (2014). Effect of cowpea (Vigna sinensis L.) with maize (Zea mays L.) intercropping on yield and its components. World Academy of Science, Engineering and Technology Inter. J. of Biolog. Veter. Agric. and Food Engin. 8 (11): 1170-1176.

He, H.; L. Yang; L. Fan; L. Zhao; H. Wu; J. Yang and C. Li (2012). The effect of intercropping of maize and soybean on microclimate. In D. Li \& Y. Chen (Eds.), Computer and Computing Technologies in Agriculture. Advances in Information and Communication Technology $369: 257-263$.

Jaiswal A.; V. Pandurangam and S. K. Sharma (2014). Effect of salicylic acid in soybean (Glycine max 1. Meril) under salinity stress. Inter. quality J. of life sci. 9(2): 671-676.

Katyayan, A. (2005). Fundamentals of agriculture. (Ed.) Varanasi, Uttar Pradesh: Kushal Publications \& Distributors. 10-11.
Khan W.; B. Prithiviraj and D. Smith (2003). Photosynthetic response of corn and soybean to foliar application of salicylates. J Plant Physiol., 160(5): 485-492.

Lithourgidis, A.; C. Dordas; C. Damalas and D. Vlachostergios (2011). Annual intercrops: An alternative pathway for sustainable agriculture. Australian J. of Crop Sci., 5: 396-410.

Metwally, A. A.; M. M. Shafik; K. E. El-Habbak and Sh. I. Abdel-Wahab (2009). Step forward for increasing intercropped soybean yield with maize. The $4^{\text {th }}$ Conference, Recent Technologies in Agriculture, 3 5 Nov., Cairo University, 2: 256 - 269.

Metwally, A.; M. Shafik; W. El Morshedy and H. Aly (2005). Yield and land equivalent ratios of intercropped maize and soybean. In Proceeding of $1^{\text {st }}$ Science Conference on Cereal Crops, Alex., 113-120.

Mobasser, H. R.; M. R. Vazirimehr and K. Rigi (2014) Effect of intercropping on resources use, weed management and forage quality. International Journal of Plant, Animal and Environmental Sciences, 4: 706-713.

MSTAT-C (1991). Michigan State University. East Lansing. USA.

Regehr, A.; M. Oelbermann; C. Videla and L. Echarte (2015). Gross nitrogen mineralization and immobilization in temperate maize-soybean intercrops. Plant and Soil, 391: 353-365.

Said M. T. and A. M. A. Abd El-Moneem (2016). Response of two bread wheat cultivars to foliar spray by salicylic and ascorbic acids under water stress conditions. Assiut J. Agric. Sci., 47: (6-2) 391-404.

Salama, K. H. A. (2009). Amelioration of NaCl-induced alterations on the plasma membrane of Allium cepa $\mathrm{L}$. by ascorbic acid. Aust. J Basic Appl. Sci., 3: 990-994.

Steel G. D. and J. H. Torrie (1981). Principles and Procedures of Statistics ( $2^{\text {nd }}$ edition) McGraw-Hill Book Company. Inc. N. Y. xxi -633.

Tufail A.; M. Arfan; A. R. Gurmani; A. Khan and A. Bano (2013). Salicylic acid induced salinity tolerance in maize (Zea mays). Pak. J. Bot., 45(1): 75-82.

Waktola, S. K.; K. Belete and T. Tana (2014). Productivity evaluation of maize-soybean intercropping system under rainfed condition at Bench-Maji Zone, Ethiopia. Sky J. of Agric. Res., 3: 158-164.

Willey, R.W. (1979). Intercropping its importance and research needs. Part 1: Competition and yield advantages Field Crops Abst., 32: 1-10.

Zilic S.; V. h. Sukalovic; V. Maksimovic; M. Maksimović; Z. Basic; Vesna Peric and J. D. Maksimovic (2010). Antioxidant properties of soybean with black and yellow kernel coat $46^{\text {th }}$ Croatian and $6^{\text {th }}$ International Symposium on Agriculture. Opatija. Croatia., pp: 686-689.

\footnotetext{
تأثير الرش الورقي بمضادات الأكسدة ونظم تحميل الأرة الثامية وفول الصويا على المحصول ومكوناته

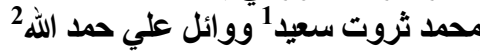

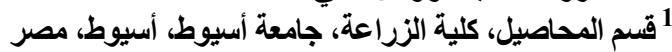

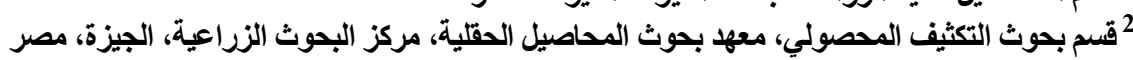

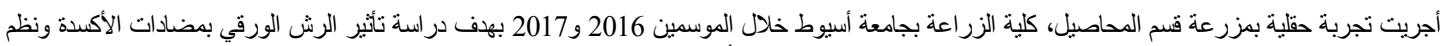

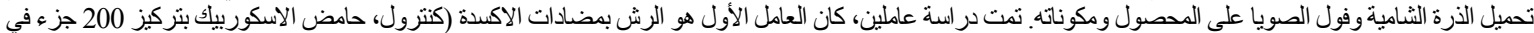

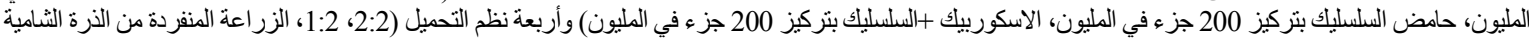

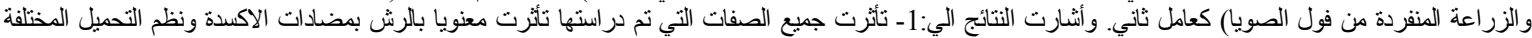

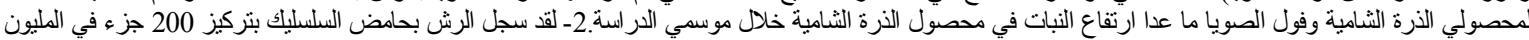

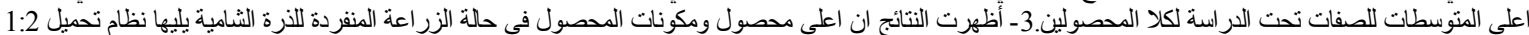

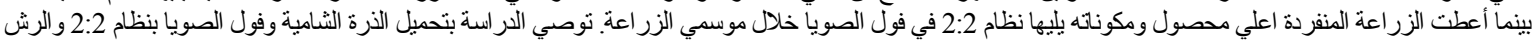
الورقي بحامض السلسليك بتركيز 200 جزء في المليون حيث سجل اعلي معدل استغلال الأرض وضلئل العائد الاقتصادي من وحدة المساحة تحت ظروف محافظة أسيوط.
} 